\title{
Medicinal Marijuana for Epilepsy: A Case Series Study
}

\author{
Lady Diana Ladino, Lizbeth Hernández-Ronquillo, José Francisco Téllez-Zenteno
}

\begin{abstract}
Objective: To describe the social, clinical and use-patterns characteristics of medicinal marijuana use among patients with epilepsy (PWEs). Methods: Eighteen PWEs with prescriptions for medicinal marijuana from a Canadian adult-epilepsy clinic were included in this study. Results: Eighteen patients had a prescription of medicinal marijuana from a total population of 800 PWEs in our center (2.2\%). Mean age of patients was $30 \pm 7.4$ (19-50) years. Twelve (67\%) patients were males. Eleven (61\%) patients had drugresistant epilepsy. Eleven $(61 \%)$ patients suffered a psychiatric comorbidity and reported the use of illicit substances or heavy alcohol or tobacco consumption. Only two (11\%) patients were married; the rest of patients $(89 \%)$ were single or divorced. The drug use pattern was similar among patients. All patients asked for marijuana permission in the epilepsy clinic. Most (83\%) had a previous history of marijuana smoking, with a mean of $6.6 \pm 3(1-15)$ years. The mean consumption dose was $2.05 \pm 1.8(0.5-8)$ grams per day. Ten (56\%) patients reported withdrawal seizure exacerbation when they stopped the marijuana. Only two patients (11\%) reported side effects, and all patients found medicinal marijuana very helpful for seizure control and improvement of mood disorder. Conclusions: PWEs using medicinal marijuana have a common profile. They are usually young single men with drug-resistant epilepsy and psychiatric comorbidity. Most used marijuana before formal prescription and all believe the drug was effective on their seizure control. Because of the concurrent use of other antiseizure medications, it is complex to estimate the actual effect of marijuana.
\end{abstract}

RÉSUMÉ: La marijuana médicinale contre l'épilepsie : étude d'une série de cas. Objectif: Détailler les caractéristiques sociales, cliniques et d'utilisation de la marijuana médicinale chez les patients atteints d'épilepsie. Méthodes: Dix-huit patients atteints d'épilepsie ayant des ordonnances de prescriptions de marijuana médicinale délivrées par une clinique canadienne d'épilepsie de l'adulte ont été inclus dans cette étude. Résultats: Sur une population totale de 800 patients atteints d'épilepsie et suivis dans notre centre, 18 (2,2\%) avaient une ordonnance de marijuana médicinale. L'âge moyen des patients était de $30 \pm 7,4$ (19-50) ans. Douze (67\%) patients étaient des hommes. Onze (61\%) patients avaient une épilepsie résistante aux médicaments. Onze (61\%) patients souffraient d'une comorbidité psychiatrique et avaient signalé l'utilisation de substances illicites ou une forte consommation d'alcool ou de tabac. Seuls, deux (11\%) patients étaient mariés; les autres patients (89\%) étaient célibataires ou divorcés. Les caractéristiques d'utilisation des drogues étaient similaires pour tous les patients. Tous les patients ont demandé la permission de consommation de marijuana à la clinique d'épilepsie. La majorité d'entre eux (83\%) avaient des antécédents de consommation de marijuana depuis, en moyenne, 6,6 \pm 3 (1-15) ans. La dose moyenne consommée était de 2,05 \pm 1,8 (0,5-8) grammes par jour. Dix (56\%) patients ont décrit une exacerbation de sevrage des crises convulsives lorsqu'ils ont arrêté la marijuana. Seulement deux patients (11\%) ont signalé des effets indésirables et tous les patients ont trouvé que la marijuana médicinale était très utile pour le contrôle des crises et l'amélioration des troubles de l'humeur. Conclusions: Les patients atteints d'épilepsie utilisant de la marijuana médicinale ont un profil commun. Ils sont habituellement jeunes, célibataires, atteints d'une épilepsie résistant aux médicaments et ils ont une comorbidité psychiatrique. La majorité d'entre eux utilisait la marijuana avant une ordonnance officielle et tous croient que la drogue est efficace pour le contrôle de leur crise. Compte tenu de l'utilisation concomitante d'autres médicaments antiépileptiques, il est difficile d'évaluer l'effet véritable de la marijuana.

Keywords: Anticonvulsant, cannabis, cannabinoids, medicinal marijuana, seizures

doi:10.1017/cjn.2014.37

Can J Neurol Sci. 2014; 41: 753-758

Marijuana contains more than 460 known different chemicals, including cannabinoids, which exert their actions by binding to the cannabinoid receptor $\mathrm{CB} 1 .{ }^{1} \mathrm{CB} 1$ receptors are the most highly expressed $G$ protein-coupled receptors in the brain ${ }^{2}$ and seem to modulate psychoactive effects, motor control, memory processing, and pain. ${ }^{3}$ The cannabinoid system provides protection against excessive neuronal activity by reducing excitability of hippocampal pyramidal neurons, ${ }^{4}$ and tetrahydrocannabinol (THC) is associated with a serotonin-mediated anticonvulsant effect, according to one experimental study in rats. ${ }^{5}$ Because of all the possible therapeutic applications, marijuana has been used for medical purposes around the world.
Canada is the first country that introduced a regulatory system for medicinal marijuana after a Supreme Court ruling. Legal access has been available since $2001,{ }^{6}$ and the number of patients authorized to use marijuana for medicinal purposes in Canada has

From the Department of Medicine, Division of Neurology, Saskatchewan Epilepsy Program (LDL, LH-R, JFT-Z), University of Saskatchewan, Saskatoon, Canada; Department of Neurology (LDL), Hospital Pablo Tobón Uribe, Medellín, Colombia, South America.

Received June 10, 2014. Final Revisions Submitted July 9, 2014 Correspondence to: José Francisco Téllez-Zenteno, Division of Neurology, Department of Medicine, Royal University Hospital, 103 Hospital Drive, Box 26, Room 1622, Saskatoon, SK. S7N OW8 Canada. Email: jose.tellez@usask.ca 
grown from approximately 500 people in 2002 to more than

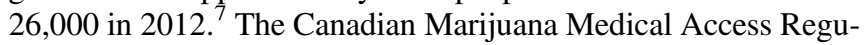
lations program allows patients to apply for a license to possess dried marijuana for medicinal purposes if traditional therapies have failed. ${ }^{8}$ Under these regulations, patients with symptoms such as nausea, anorexia, cachexia, weight loss, muscle spasms, pain, and seizures associated with multiple sclerosis, severe arthritis, AIDS, cancer, spinal cord injuries or diseases, and epilepsy can possess marijuana legally. ${ }^{9}$

The scientific evidence about the anticonvulsant action of marijuana on humans is scanty and controversial. In general, physicians remain unsure whether there are benefits of marijuana that outweigh the risks for patients with epilepsy (PWEs). We aimed to investigate the sociodemographic and clinical characteristics of a group of PWEs with a formal prescription for medicinal marijuana; in addition, we explored the potential clinical effects experienced by patients.

\section{MeTHODS}

This study was performed at the Royal University Hospital in Saskatoon, Saskatchewan, Canada. A retrospective review of the 800 clinical charts from the epilepsy outpatient clinic was performed between May and November 2013. Adult PWEs that are authorized to possess dried marijuana for medical purposes were identified and enrolled in the study. The marijuana authorization was given to (1) patients with drug-resistant epilepsy (DRE) who were on polytherapy without response; (2) patients with serious antiepileptic drug (AED) side effects; or (3) patients who asked for authorization and reported beneficial effects of unauthorized marijuana use on epilepsy.

Patients who had consumed marijuana before the medicinal prescription were defined as previous users. Patients who had consumed marijuana at least 48 times the year before the medicinal prescription were defined as previous active users. Patients who had active users as a member of their family or a close friend were defined as patients with family or friend consumption. When a patient reported that marijuana withdrawal produces seizures that only can be controlled with a new dose of marijuana or hospital emergency treatment, they were defined as patients with withdrawal seizure exacerbation. Side effects were considered positive when a patient had to stop marijuana consumption or go to the hospital because of adverse effects. Patients with a history of smoking more than ten cigarettes per day were considered moderate to heavy tobacco smokers. Male patients consuming of more than two drinks per day, or more than 14 drinks per week, and female patients consuming of more than one drink per day, or more than seven drinks per week, were defined as heavy alcohol drinkers. A member of the patient's family living with medical or social conditions such as severe depression, alcoholism, active illicit drug use, or pathological gambling were defined as dysfunction in the family. When police had arrested a patient, it was defined as having problems with the law.

The estimated median total income before taxes was obtained from the wealth of demographic data for each residential neighborhood in Saskatoon ${ }^{10,11}$ or the town or village where the patient was living. ${ }^{12}$ All these data were gathered from the Canadian Federal Census. The estimated grams in every puff of marijuana were calculated according to Health Canada recommendations. ${ }^{9}$ Every joint of marijuana contains 0.5 to $1 \mathrm{~g}$ of drug and approximately $20 \%$ to $70 \%$ of THC is delivered in the smoke.
The following information was gathered from charts: epilepsy type, seizures type, and epilepsy syndrome. This information was classified according the recommendations of the International League Against Epilepsy. ${ }^{13}$ DRE was determined using the new definitions of the International League Against Epilepsy. ${ }^{14}$ The history of marijuana consumption was documented in each patient.

\section{Analysis}

Descriptive statistics were used according to the type of variable measured. All analysis was performed using SPSS version 20 (SPSS Inc., Chicago, IL, USA).

\section{RESULTS}

\section{Demographic Variables}

Eighteen patients (12 men and 6 women) were identified holding a prescription of medicinal marijuana from a total population of 800 PWEs in the Saskatchewan epilepsy center (2.2\%). The majority of patients were Caucasian $(89 \%)$ and male $(67 \%)$ (Table 1). The average median household income of patients before taxes was $\$ 52.568 \pm 31.421$ (\$18.401-120.042).

\section{Clinic Variables}

Mean age of patients was $30 \pm 7$ (19-50) years. The mean age at epilepsy diagnosis was $16 \pm 11(1-43)$ years. Forty-four percent

Table 1: Demographics of the patient population

\begin{tabular}{|c|c|c|}
\hline Variable & Category & $\begin{array}{c}\text { Total sample }(\mathrm{N}=18) \\
\mathrm{N}(\%)\end{array}$ \\
\hline \multirow[t]{2}{*}{ Sex } & Male & $12(67)$ \\
\hline & Female & $6(33)$ \\
\hline \multirow[t]{3}{*}{ Ethnicity } & Caucasian & $16(89)$ \\
\hline & First Nation & $1(5.5)$ \\
\hline & Hispanic & $1(5.5)$ \\
\hline \multirow[t]{3}{*}{ Marital status } & Single & $14(78)$ \\
\hline & Divorced & $2(11)$ \\
\hline & Married & $2(11)$ \\
\hline \multirow[t]{2}{*}{ Level of education } & $\begin{array}{l}\text { High school or } \\
\text { less }\end{array}$ & $14(78)$ \\
\hline & College & $4(22)$ \\
\hline \multirow[t]{2}{*}{ Driving } & Driving license & $11(61)$ \\
\hline & $\begin{array}{l}\text { No driving } \\
\text { license }\end{array}$ & $7(39)$ \\
\hline \multirow[t]{3}{*}{ Employment } & Employed & $9(50)$ \\
\hline & Unemployed & $9(50)$ \\
\hline & $\begin{array}{l}\text { Disability } \\
\text { insurance }\end{array}$ & $6(33)$ \\
\hline \multirow{3}{*}{$\begin{array}{l}\text { Estimated median total household } \\
\text { income }\end{array}$} & $<\$ 20,000$ & $1(6)$ \\
\hline & $\begin{array}{l}\$ 20,000- \\
60,000\end{array}$ & $9(50)$ \\
\hline & $>\$ 60,000$ & $8(44)$ \\
\hline \multirow[t]{2}{*}{ Residence } & Urban & $12(66)$ \\
\hline & Rural & $6(33)$ \\
\hline
\end{tabular}


Table 2: Clinical characteristics of patients

\begin{tabular}{|c|c|c|}
\hline Variable & Category & $\begin{array}{c}\text { Total sample }(\mathrm{n}=18) \\
\mathrm{N}(\%)\end{array}$ \\
\hline \multirow[t]{2}{*}{ Epilepsy classification } & Focal & $11(61)$ \\
\hline & Generalized & $7(39)$ \\
\hline \multirow[t]{3}{*}{ Syndrome classification } & Symptomatic & $7(39)$ \\
\hline & Cryptogenic & $6(33)$ \\
\hline & Idiopathic & $5(28)$ \\
\hline \multirow[t]{6}{*}{ Epilepsy etiology } & Mesial temporal sclerosis & $4(22)$ \\
\hline & Idiopathic & $3(17)$ \\
\hline & Tumor & $3(17)$ \\
\hline & Lennox-Gastaut syndrome & $2(11)$ \\
\hline & Congenital malformation & $2(11)$ \\
\hline & Unknown & $2(11)$ \\
\hline \multirow[t]{4}{*}{ Psychiatric comorbidity } & Depression & $7(39)$ \\
\hline & Behavioral problems & $6(33)$ \\
\hline & Anxiety disorder & $3(17)$ \\
\hline & Psychosis & $2(11)$ \\
\hline \multirow[t]{3}{*}{ Substance use } & $\begin{array}{l}\text { Moderate to heavy tobacco } \\
\text { smoker }\end{array}$ & $9(50)$ \\
\hline & Heavy alcohol drinker & $6(33)$ \\
\hline & Use stimulants* & $3(17)$ \\
\hline \multirow[t]{2}{*}{ Tattoo or piercing } & Tattoo & $7(39)$ \\
\hline & Piercing & $4(22)$ \\
\hline \multirow[t]{2}{*}{ Therapy } & Polytherapy & $13(72)$ \\
\hline & Monotherapy & $5(28)$ \\
\hline \multirow{4}{*}{$\begin{array}{l}\text { Antiepileptic drugs } \\
\text { most used }\end{array}$} & Lamotrigine & $11(61)$ \\
\hline & Levetiracetam & $8(44)$ \\
\hline & Clobazam & $7(39)$ \\
\hline & Carbamazepine & $5(28)$ \\
\hline
\end{tabular}

*Stimulants include cocaine and amphetamines.

of patients had more than one seizure per month and $44 \%$ had suffered at least one episode of status epilepticus. The mean number of seizures per month when using medicinal marijuana was $3.5 \pm 7.4(0-30)$. Developmental delay was present in five $(28 \%)$ patients. Psychiatric comorbidity was common $(61 \%)$, with depression the most frequent entity. The use of other illicit substances such as stimulants (cocaine or amphetamines), moderate to heavy smoking, or heavy alcohol drinking was also common (61\%) (Table 2).

Eleven $(61 \%)$ patients had DRE and were also refractory to treatments such as vagal nerve stimulation or ketogenic diet. Seven $(39 \%)$ patients underwent epilepsy surgery. Three patients had temporal lobectomies, two had callosotomies, and two had tumor resections. Patients had used a large number of AEDs in the past, with a mean of $5 \pm 3.5$ (1-15). In the last follow-up, patients were using $2.4 \pm 1.1$ (1-4) AEDs. Fifty percent (5/10) had undergone epilepsy surgery without seizure control, and $20 \%(2 / 10)$ had complex congenital malformations without the possibility of surgical management.

\section{Social Variables}

Five $(28 \%)$ patients had committed criminal offenses. Three $(17 \%)$ patients were arrested by the police because of frequent postictal violent episodes, one patient was incarcerated because of drug dealing, and one had been arrested on many occasions for unknown reasons. Regarding the families, nine (50\%) patients had a family members or close friends who consumed marijuana and eight (44\%) patients had a clear history of family dysfunction. Four patients in the study were two pairs of brothers. One was a twin, and both brothers had temporal lobe epilepsy.

\section{Marijuana Consumption}

The drug-use pattern was similar among patients (Table 3). Most (89\%) had a long history of marijuana use before obtaining a formal prescription, with a mean of $6.6 \pm 3.4$ (1-15) years. Only two (11\%) patients started the medication de novo with the medicinal prescription. These two patients (patients 5 and 11) were complex cases with Lennox-Gastaut syndrome and developmental delay treated with polytherapy, vagal nerve stimulation, and callosotomy without response. In these cases, the family asked for the prescription as a last treatment resource.

Administration route was through cigarettes (smoking) in $15(83 \%)$ patients. Two (11\%) patients used marijuana in a "special beverage made at home" by the family (patients 5 and 11 ) and one (5\%) patient used marijuana through vaporization (patient 15). This patient used a vaporizer that heats the plant to release cannabinoids, but remains cool enough to avoid the smoke and toxins associated with combustion. The mean of puff per day when smoking was $4.05 \pm 2.87$ (0.5-8). In general, the estimated mean consumption was $2.05 \pm 1.87(0.5-8)$ $\mathrm{g}$ per day. Four patients had permission to grow marijuana at home.

Regarding the mode of access, all patients had permission to purchase marijuana from Health Canada, although the sources were variable: four $(22 \%)$ patients admitted to buying the drug from the government, four $(22 \%)$ grew and consumed their own marijuana, five (28\%) got it from a friend, and the rest (28\%) admitted to buying the drug on the street. Only two (11\%) patients reported the use of complementary and alternative medicine (CAM) treatments before the marijuana authorization, such as botanical/herbals, vitamins, homeopathic treatment, chiropractic treatment, yoga, special diets, and other "healing therapies."

In terms of physical and psycho-affective effects, eight (44\%) patients never stopped marijuana consumption since receiving their prescriptions, and the other ten (56\%) patients have stopped the drug only in special circumstances, such as long flights. All patients that stopped the drug reported exacerbation of withdrawal seizures. None reported status epilepticus as a complication. Only two patients $(11 \%)$ reported side effects (Table 3 ). One patient reported an episode of severe motor slowing and drowsiness with drug consumption and another reported complex hallucinations related with paranoid thoughts that required follow-up with a psychiatrist. This patient had a prior diagnosis of psychosis. These patients reported that the benefits of using marijuana outweighed the side effects in every case.

Overall, the mean follow-up since the medical prescription was issued was $26 \pm 18$ (1-55) months. All patients found 
Table 3: Marijuana pattern of use between patients

\begin{tabular}{|c|c|c|c|c|c|c|c|c|c|c|}
\hline$\#$ & Sex & $\begin{array}{l}\text { Age, } \\
\mathbf{y}\end{array}$ & $\begin{array}{l}\text { Previous } \\
\text { user }\end{array}$ & $\begin{array}{l}\text { Active } \\
\text { user }\end{array}$ & $\begin{array}{l}\text { Family } \\
\text { user }\end{array}$ & $\begin{array}{c}\text { Mode of } \\
\text { use }\end{array}$ & $\begin{array}{c}\text { Other } \\
\text { substances }\end{array}$ & $\begin{array}{l}\text { Side effects with } \\
\text { withdrawal }\end{array}$ & Side effects & $\begin{array}{c}\text { Mode of } \\
\text { access }\end{array}$ \\
\hline 1 & $\mathrm{M}$ & 33 & Yes & Yes & Yes & Smoke & SC, HTS & Yes & No & Friend \\
\hline 2 & $M$ & 30 & Yes & Yes & No & Smoke & HTS & Yes & Hallucinations & Friend \\
\hline 3 & $F$ & 29 & Yes & Yes & No & Smoke & HAD, HTS & Yes & No & Street \\
\hline 4 & M & 35 & Yes & Yes & Yes & Smoke & SC, HAD, HTS & Yes & No & Street \\
\hline 5 & $\mathrm{M}$ & 26 & No & No & No & Oral & No & Never stopped & No & $\mathrm{HC}$ \\
\hline 6 & $F$ & 25 & Yes & Yes & Yes & Smoke & SC, HAD, HTS & Never stopped & No & Street \\
\hline 7 & M & 29 & Yes & Yes & Yes & Smoke & HAD & Never stopped & Drowsiness & Grow \\
\hline 8 & $\mathrm{M}$ & 27 & Yes & Yes & Yes & Smoke & No & Yes & No & Grow \\
\hline 9 & $\mathrm{~F}$ & 36 & Yes & Yes & No & Smoke & HTS & Never stopped & No & Friend \\
\hline 10 & M & 39 & Yes & Yes & No & Smoke & HTS & Never stopped & No & Friend \\
\hline 11 & M & 25 & No & No & Yes & Oral & No & Yes & No & $\mathrm{HC}$ \\
\hline 12 & $F$ & 19 & Yes & Yes & Yes & Smoke & HAD & Never stopped & No & Street \\
\hline 13 & $\mathrm{M}$ & 24 & Yes & Yes & Yes & Smoke & HAD, HTS & Yes & No & Street \\
\hline 14 & M & 21 & Yes & Yes & Yes & Smoke & No & Yes & No & $\mathrm{HC}$ \\
\hline 15 & $\mathrm{~F}$ & 34 & Yes & Yes & No & Vaporize & No & Never stopped & No & $\mathrm{HC}$ \\
\hline 16 & $\mathrm{M}$ & 50 & Yes & Yes & No & Smoke & No & Yes & No & Grow \\
\hline 17 & $\mathrm{M}$ & 38 & Yes & Yes & No & Smoke & No & Never stopped & No & Grow \\
\hline 18 & F & 29 & Yes & Yes & No & Smoke & HTS & Yes & No & Friend \\
\hline
\end{tabular}

$\mathrm{SC}=$ stimulant consumption; DRE = drug-resistant epilepsy; HAD = heavy alcohol drinker; HC: Health Canada; HTS = heavy tobacco smoker;

$\mathrm{SE}=$ seizure exacerbation

Table 4: Personal experiences of patients using medical marijuana

\begin{tabular}{l|c|c|c|c|c|c|c}
\hline $\begin{array}{l}\text { Effects } \\
\mathbf{N}=\mathbf{1 8}\end{array}$ & $\begin{array}{c}\text { Seizure severity N } \\
(\boldsymbol{\%})\end{array}$ & $\begin{array}{c}\text { Seizure frequency N } \\
(\boldsymbol{\%})\end{array}$ & $\begin{array}{c}\text { AED side effects N } \\
(\boldsymbol{\%})\end{array}$ & $\begin{array}{c}\text { Mood disorders N } \\
(\boldsymbol{\%})\end{array}$ & $\begin{array}{c}\text { Sleep quality N } \\
(\boldsymbol{\%})\end{array}$ & $\begin{array}{c}\text { Appetite } \mathbf{N} \\
(\boldsymbol{\%})\end{array}$ & $\begin{array}{c}\text { General well-being N } \\
(\boldsymbol{\%})\end{array}$ \\
\hline Improved & $18(100)$ & $18(100)$ & $2(11)$ & $18(100)$ & $16(89)$ & $16(89)$ & $18(100)$ \\
\hline Worsened & $0(0)$ & $0(0)$ & $0(0)$ & $0(0)$ & $0(0)$ & $0(0)$ & $0(0)$ \\
\hline No effect & $0(0)$ & $0(0)$ & $16(89)$ & $0(0)$ & $2(11)$ & $2(11)$ & $0(0)$ \\
\hline
\end{tabular}

marijuana consumption very helpful for seizure control (Table 4). Additionally, they reported relief of poor sleep, poor appetite, and mood difficulties. All patients wanted to continue with the medical prescription and reported excellent daily marijuana compliance.

\section{Discussion}

There is lack of scientific evidence to endorse marijuana as a medical therapy. There are many concerns from trials such as inconsistency of dosage, number of patients included, and time of treatment. ${ }^{15}$ Additionally there are fears about potential side effects reported in cultured rat hippocampal cells. According to in vitro experiments, THC may induce neuronal death. ${ }^{16}$ In 1976 , Feeney published the results of a survey of PWEs in the United States. He reported that $29 \%$ of patients younger than age 30 used illegal marijuana after being diagnosed with epilepsy. ${ }^{17}$ Almost 40 years later, the use of marijuana for neurological diseases has increased dramatically. ${ }^{18}$ However, reports of patients with formal prescriptions are scanty. To the best of our knowledge, this is the first case series study in the literature reporting the potential benefit of medicinal marijuana in adult PWEs.

\section{Demographics}

Common sociodemographic features of our patients include young age (19-55 years) and being Caucasian and male. These findings are comparable to the characteristics of people who reported marijuana consumption in the general Canadian population ${ }^{19}$ and in patients that use the drug for medical purposes (including epilepsy). ${ }^{18,20}$ The characteristics of our patients are also similar to the patients reported in other series of PWEs. A recent study reported that males (odds ratio 5.342, 95\% confidence interval 1.41-20.15) and young people with epilepsy had a higher chance of being active marijuana users. ${ }^{21}$ Using a standardized telephone survey, Gross et al. ${ }^{22}$ reported a high active use of marijuana (drug use within the past year) in PWEs (21\%). This study did not show any significant association between marijuana use with age or gender. ${ }^{22}$ In agreement with other studies, ${ }^{18,20}$ our patients reported using marijuana before the formal 
prescription was issued and that smoking was the main route of administration. ${ }^{18,20}$

\section{Effects of Marijuana on Epilepsy}

The effects of marijuana on epilepsy are controversial. Some studies report no clear effect of marijuana on seizures and others report a beneficial effect. Interestingly, in our study, the entire population reported a reduction in seizure frequency and severity as well as improved mood and general well-being. Aside from the seizure effects, our patients $(89 \%)$ reported improved sleep quality and appetite (Table 4). Our results are in agreement with a standardized telephone survey performed by Gross et $\mathrm{al}^{22}$ in Canadian PWEs. In this study, 68\% of active marijuana users reported improvement in seizure severity and 54\% reported decreased seizure frequency. The rest of patients reported no effect on the seizures, and none reported worsening. ${ }^{22}$ A survey of Canadian consumers of marijuana for different medical purposes showed that in general the drug was perceived to provide effective symptoms relief. More than $70 \%$ of patients reported that marijuana was always helpful and $24 \%$ described it as often helpful. ${ }^{18}$ A positive perception was also reported in an online survey addressing the personal experiences of patients in the federal cannabis program. Marijuana was perceived to be an effective treatment for symptoms including pain, nausea, and negative mood. ${ }^{20}$

Not all the studies show positive results. A recent study performed in a German outpatient epilepsy clinic $^{21}$ showed that most patients who had consumed marijuana did not observe any effect on the disease (84\%). Only $15 \%$ of active users experienced indirect positive effects on the disease, such as relief from postictal headaches, vomiting, and cramps, and only one patient reported that marijuana helped to reduce the frequency of seizures. ${ }^{21}$ In contrast with other studies and ours, seven (11\%) patients reported increased seizure frequency associated with marijuana consumption. ${ }^{21}$ These negative results are consistent with an American study in which informal interviews were performed in 215 PWEs. In that study, $90 \%$ of the patients failed to identify a relationship between marijuana use and seizure frequency or severity. Seven percent believed seizures were less frequent around the time of consumption and $2 \%$ believed were more frequent. ${ }^{23}$ However, all of the available studies, including ours, represent samples of patients with self-reported experiences with no formal quantification of seizures or measurements of seizure severity. Also none of the available studies evaluated quality of life before and after the use of marijuana.

\section{Safety}

In our study, only two patients reported side effects. According to a recent analysis of four small, randomized clinical trials (48 patients), the dose of 2 to $3 \mathrm{~g}$ of Cannabidiol seems to be safe in the short-term (4-24 weeks) in PWEs. Only one clinical trial reported drowsiness. All the studies included in this Cochrane review did not report side effects on patients. ${ }^{15}$ Furthermore, in our case series, $10(56 \%)$ patients reported seizure exacerbation after stopping the drug, a phenomenon previously reported in humans by Hedge et al. ${ }^{24}$ Animal models have also shown rebound effects to THC. Apparently, after exposure to the drug, the withdrawal phase enhances central nervous system excitability, resulting in increased susceptibility to convulsions. ${ }^{25}$

\section{Psychoactive Substances and Psychiatric Comorbidities}

Half of the PWEs tried CAM treatments for seizure control. ${ }^{26}$ However, neither seizure frequency nor the number of AEDs predicted the use of CAMs. ${ }^{27}$ Marijuana is a drug accepted as a CAM treatment. ${ }^{26}$ Individuals who use marijuana are also more likely to use other illicit substances, according to some studies, ${ }^{22,28}$ and to have a higher tendency to develop psychiatric comorbidity $^{29}$ as well as being involved with other drug users. ${ }^{19}$ The use of other substances (61\%) and the presence of psychiatric comorbidity $(61 \%)$ were common in our patients. Paradoxically, PWEs use marijuana to improve their seizures, although seizure worsening with frequent use of other illicit drugs has been described. ${ }^{21}$ The use of illicit substances other than marijuana and the significant psychiatric comorbidity in our patients might explain the high rate of being single, unemployed, and having problems with the law.

\section{Marijuana Access}

We found that the majority of patients admitted accessing cannabis through places other than Health Canada (88\%). Overall, patients in our study reported lack of satisfaction with the quality of the cannabis supplied by the government. This finding is consistent with a survey performed in 100 federally authorized users. According to that survey, $72 \%$ of users reported they were unsatisfied with Canada's medical cannabis program. When participants were asked about their preferred source for medical cannabis, $99 \%$ reported a place different than Health Canada. ${ }^{20}$ Similar findings were reported on an online survey of 628 Canadian consumers of cannabis for therapeutic purposes. ${ }^{18}$

\section{Limitations}

Our study is retrospective and mainly based in self-reported effects of patients, with no formal quantification of seizure frequency and severity. As a result, our results should be interpreted with caution. Another limitation is the lack of a control group. The reduced sample size of this study is the main limitation to performing a direct comparison with another group of PWEs. Our group of patients probably does not reflect the profile of the general population of PWEs, although our study provides critical information in an area where there is controversy and a lack of evidence.

\section{Conclusions}

This study shows potential positive effects on seizure activity using medicinal marijuana, but has limitations; therefore, we cannot recommend the use of marijuana for all PWEs. It is possible that some patients could have benefits from medicinal marijuana, such as patients with DRE who are not candidates for epilepsy surgery or in whom surgery did not work. Further prospective studies and randomized clinical trials should examine the potential effect of medicinal marijuana on seizures. The debate will continue until more research is performed. This is one of the few available descriptions of using marijuana as a treatment for epilepsy.

\section{Disclosures}

JFT-Z receives grants from the University of Saskatchewan and the Royal University Hospital Foundation in Saskatoon, Saskatchewan, through the Mudjadik Thyssen Mining Professorship in Neurosciences. 


\section{REFERENCES}

1. Ben Amar M. Cannabinoids in medicine: a review of their therapeutic potential. J Ethnopharmacol. 2006;105(1-2):1-25.

2. Wilson RI, Nicoll RA. Endogenous cannabinoids mediate retrograde signaling at hippocampal synapses. Nature. 2001;410:588-92.

3. Wingerchuk D. Cannabis for medical purposes: cultivating science, weeding out the fiction. Lancet. 2004;364(9431):315-6.

4. Wallace R. Cannabinoids: defending the epileptic brain. Epilepsy Curr. 2004;4(3):93-5.

5. Ghosh P, Bhattacharya SK. Anticonvulsant action of cannabis in the rat: role of brain monoamines. Psychopharmacology (Berl). 1978;59(3):293-7.

6. Santry C. Canadian doctors say it is inappropriate for them to prescribe marijuana. BMJ. 2012;345:e8623.

7. Health Canada government website. Harper government announces new marihuana for medical purposes regulations: Changes improve public safety and maintain patient access. [Updated 2013 Jun 10]. Available from: http://www.hc-sc.gc.ca/ahc-asc/media/ nr-cp/_2013/2013-79-eng.php.

8. Health Canada government website. Drug and health products: medical use of marihuana. About the marijuana medical access program. [Updated 2013 Jun 20]. Available from: http:// http://www. hc-sc.gc.ca/dhp-mps/marihuana/about-apropos/index-eng.php.

9. Justice Laws Website. Marijuana Medical Access Regulations SOR/2001-227. [Updated 2013 December 9]. Available from: http://laws-lois.justice.gc.ca/eng/regulations/SOR-2001-227/page-2. html\#s-5.

10. Saskatoon.ca. City of Saskatoon neighborhood profiles. 2011 census/2012 estimates/demographic and housing data. [Updated 2012 July 9]. Available from: http://www.saskatoon.ca/ DEPARTMENTS/Community\%20Services/PlanningDevelopment/ Documents/Research/Neighbourhood_profiles/2012/Neighbourhood \%20Profiles.pdf.

11. Government of Canada website. Statistics Canada. Median total income, by family type, by province and territory (all census families). [Updated 2012 February 8]. Available from: http:// www.statcan.gc.ca/tables-tableaux/sum-som/101/cst01/famil108aeng.htm.

12. City-Data.com. Saskatchewan agglomerations, cities, towns and villages. The median total income before taxes. [Updated 2013 March]. Available from: http://www.city-data.com/canada/ Saskatchewan-Index.html.

13. Commission on Classification and Terminology of the International League Against Epilepsy. Proposal for revised classification of epilepsies and epileptic syndromes. Epilepsia. 1989;30:389-399.
14. Kwan P, Arzimanoglou A, Berg AT, et al. Definition of drug resistant epilepsy: consensus proposal by the ad hoc Task Force of the ILAE Commission on Therapeutic Strategies. Epilepsia. 2010; 51(6): 1069-77.

15. Gloss D, Vickrey B.. Cannabinoids for epilepsy. Cochrane Database of Systematic Reviews. 2012;6:CD009270.

16. Chan GC, Hinds TR, Impey S, Storm DR. Hippocampal neurotoxicity of Delta9-tetrahydrocannabinol. J Neurosci. 1998;18(14):5322-32.

17. Feeney DM. Marijuana use among epileptics. JAMA. 1976; 235(11):1105.

18. Walsh Z, Callaway R, Belle-Isle L, et al. Cannabis for therapeutic purposes: patient characteristics, access, and reasons for use. Int $\mathrm{J}$ Drug Policy. 2013;24(6):511-6.

19. Ogborne AC, Smart RG. Cannabis users in the general Canadian population. Subst Use Misuse. 2000;35(3):301-11.

20. Lucas P. It can't hurt to ask; a patient-centered quality of service assessment of health Canada's medical cannabis policy and program. Harm Reduct J. 2012;9:2-11.

21. Hamerle M, Ghaeni L, Kowski A, Weissinger F, Holtkamp M. Cannabis and other illicit drug use in epilepsy patients. Eur $\mathbf{J}$ Neurol. 2014;21(1):167-70.

22. Gross DW, Hamm J, Ashworth NL, Quigley D. Marijuana use and epilepsy: prevalence in patients of a tertiary care epilepsy center. Neurology. 2004;62(11):2095-97.

23. Gordon E, Devinsky O. Alcohol and marijuana: effects on epilepsy and use by patients with epilepsy. Epilepsia. 2001;42:1266-72.

24. Hegde M, Santos-Sanchez C, Hess CP, Kabir AA, Garcia PA. Seizure exacerbation in two patients with focal epilepsy following marijuana cessation. Epilepsy Behav. 2012;25(4):563-6.

25. Karler R, Calder LD, Turkanis SA. Prolonged CNS hyperexcitability in mice after a single exposure to delta-9tetrahydrocannabinol. Neuropharmacology. 1986;25:441-6.

26. Sirven JI, Drazkowski JF, Zimmerman RS, Bortz JJ, Shulman DL, Macleish M. Complementary/alternative medicine for epilepsy in Arizona. Neurology. 2003;61(4):576-7.

27. Easterford K, Clough P, Comish S, Lawton L, Duncan S. The use of complementary medicines and alternative practitioners in a cohort of patients with epilepsy. Epilepsy Behav. 2005;6(1):59-62.

28. Smith GW, Farrell M, Bunting BP, Houston JE, Shevlin M. Patterns of polydrug use in Great Britain: findings from a national house-hold population survey. Drug Alcohol Depend. 2011;113:222-8.

29. Connor JP, Gullo MJ, Chan G, Young RM, Hall WD, Feeney GF. Polysubstance use in cannabis users referred for treatment: drug use profiles, psychiatric comorbidity and cannabis-related beliefs. Front Psychiatry. 2013;4(79):1-7. 